\title{
Thai Catalogers' Use and Perception of Cataloging Standards
}

Hollie White ${ }^{\mathrm{a} *}$ and Songphan Choemprayong ${ }^{\mathrm{b}}$

${ }^{a}$ Library, Archives, Records and Information Science. Curtin University, Perth, Australia; ${ }^{b}$ Department of Library Science, Faculty of Arts, Chulalongkorn University, Bangkok, Thailand.

*hollie.white@curtin.edu.au 


\section{Thai Catalogers' Use and Perception of Cataloging Standards}

Library-based metadata and knowledge organization standards, such as Resource Description and Access (RDA); Dewey Decimal System (DDC); and Library of Congress Subject Headings (LCSH), are called "international" or "universal" as they are increasingly adopted by countries around the world. Yet, library knowledge organizations systems are created within given contexts representing the limited needs of specific communities in certain time periods. This article presents results from a cataloging study of Thai libraries. A focus group and interviews were used to gather data on Thai catalogers' use and perception of cataloging standards in Thai libraries and how well they meet their needs.

Keywords: internationalization of cataloging; culture and cataloging; cataloging standards; Thailand; Thai libraries

\section{Introduction}

As cataloging standards and codes become increasingly internationalized, it is essential for the cataloging experiences of librarians in non-Euro-American countries to be documented and shared. Library knowledge organizations systems are created for specific communities and contexts. ${ }^{\mathrm{iii}}$ For over a century schemes and standards created by Melvil Dewey, the Library of Congress, Otlet \& Fontaine, and other European or American bibliographers and institutions have been disseminated and promoted as international standards that can fit in many library environments.

The practice of cataloging is made up of four components: descriptive cataloging, subject cataloging, classification, and systems/software. Each part of this process involves decisions about the type of standards that will be used and how those standards will best serve library users. Because "[1]ibrary users are important people and wherever they are, whatever they want, serving them is the basis of what we [as librarians] do[,]"iii it is surprising that standards created so long ago and in a very specific context are considered not only currently relevant, but also 'international'. The 
2017 update to the National Bibliographic Register (https://www.ifla.org/node/2216), a list of bibliographic activity from 45 countries, found that Euro-American cataloging and classification standards, such as the MARC21 format and Dewey Decimal Classification System, are still most frequently used around the world. ${ }^{\text {iv }}$ The exception is in subject cataloging where specialized national thesauri are used more widely. ${ }^{\mathrm{v}}$ Understanding more about how various cultures and countries use and perceive cataloging standards is an important part of creating a more globally equitable cataloging community.

The purpose of this article is to examine how Thai catalogers use cataloging standards and their perceptions of the relevance and usefulness of those standards within the Thai context. This paper begins by reviewing the history of Thai libraries in general, as well as Thai history related to cataloging systems. The methodology section goes over the focus group and interview data collection techniques, as well as the thematic analysis deductive coding used for the study. Findings and analysis from this study are presented in four categories: descriptive cataloging, subject cataloging, classification, and systems/software. Recommendations and conclusions are presented at the end of the article.

\section{Brief History and Current State of Thai Libraries}

The history of libraries in Thailand is sporadically documented in English language resources. Most literature about Thai libraries in English focus on academic libraries, ${ }^{\mathrm{vi}}$ special libraries, or the National Library ${ }^{\text {vii }}$. Compared to library literature in western countries, little is published either historically or currently about public or school libraries in Thailand.

The history of collecting Thai materials for use and preservation started during the Sukhothai Kingdom period in the $14^{\text {th }}$ century. ${ }^{\text {vii }}$ Prior to printing, Thai manuscripts 
were in various physical forms including stone inscription, palm leaf, Khoi book, and Tai books. The history of book printing began during the Ayutthaya Kingdom period when a French missionary brought the press machine to the country. ${ }^{\text {ix }}$ Buddhist scriptures, historical records, laws, astrology records, and archival records were kept for use by families and at temples. ${ }^{\mathrm{x}}$ Temple libraries, which were the main place of education for Thai children, served as the original school or university library. King Rama III, "was the first monarch who initiated the idea of access to the book collections for the public at large". ${ }^{\mathrm{x}}$ The Royal Vajirayana Library was created in 1882 as ordered by King Rama V. This library was renamed the National Library of Thailand in 1905. Since the promulgation of the Printing Act of B.E. 2484 (1941), the National Library legally serves as a legal deposit repository. By 1975 it was the largest library in Thailand. ${ }^{\text {ii }}$

Rama VI is also responsible for the establishment of Chulalongkorn University in 1915 whose library is acknowledged as the first Thai academic library. ${ }^{\text {xiii }}$ Thai university libraries at this time, "were small with a few thousand books mostly in Thai language; and they were managed by interested faculty members and personnel". ${ }^{\text {xiv }}$ According to relevant regulations (e.g., Ministerial Regulations on Systems, Principles, and Approaches of Educational Quality Assurance of B.E. 2553 and Ministerial Regulations on Principles, Approaches, and Criteria in Seeking and Issuing a License to Establish a Private University of B.E.2549), academic library is a mandatory function to be considered for establishing higher education institutions as well as assessing the quality of education programs and institutions. Due to a wide variety of visions, missions, and administrative systems, there are numerous types of higher education institutions, for instance, public universities, public autonomous universities, Rajabhat universities (previously community teachers colleges), Rajamangala universities of 
technology (previously community technical colleges), community colleges, institutes of vocational education, military schools and colleges, private universities, and independent international institutions. The operations of the academic libraries in these institutions are varied depending on their mother institutions' strategic plans.

Prudtikul and Thalang ${ }^{\mathrm{xv}}$ cite three dates for development of school libraries in Thailand. They mention 1934 for the school library at Thepsirin School, 1961 for the Suan Kulap School, but 1956 was the year when the Department of General Education in the Ministry of Education took on the responsibility of advising and assisting the arrangement of school libraries.

Thai public libraries developed from Bangkok public reading rooms created by the Education Department in $1916 .{ }^{\mathrm{x} i}$ Similar to school libraries, the Minister of Education took efforts in the late 1940s and 1950s to expand public libraries. In 1949 there were 20 public libraries; this number grew to 64 in 1950 and by 1999 there were $850 .{ }^{x v i i}$

Special libraries have a longer history. The first special library was founded in 1887 at the Ministry of Education ${ }^{\text {xviii }}$. In the late 1990s, Siripan ${ }^{\text {xix }}$ divided Thai special libraries into eight categories: government based; state enterprises; associations and societies; banks and other financial institutions; research institutions; academic institutions; international organizations and institutes; and other libraries not falling into one of the other categories. Many special libraries in Thailand are called 'information centers.'

The Thai term 'bannarak' or 'a person who takes care of books' appeared in the first official Thai language dictionary in $1927 .{ }^{\mathrm{xx}}$ The term 'library' in Thai, hongsamut, is a compound word joining two terms: book (samut) and room (hong). 
Current English language-based literature on Thai libraries is limited, with articles focusing on special materials ${ }^{\mathrm{xxi}}$ or specific service implementation. ${ }^{\mathrm{xxii}}$ Even the current statistics on the number of libraries in Thailand is unclear. The Thai Library Association (http://tla.or.th/) was originally established in $1954^{\text {xxiii }}$ and today serves as a vibrant organization that facilitates conferences and other continuing professional development programming. Yet, this group does not provide statistics about various library sectors or librarians. The most recent national-level Thai library statistics are found in the 2007 IFLA World Report indicating that about a decade ago there were, “919 public libraries, 225 university libraries, 54,133 school libraries and 180 government-funded research libraries." ${ }^{\text {xxiv }}$ These numbers have most likely changed since their original publication.

\section{Thai Cataloging History}

Sindusopon $^{\mathrm{xxv}}$ sees a link between the development of Thai library science education in the 1950s and the systemic use of cataloging standards in Thai libraries. This use of cataloging standards includes, "[s]ystematic classification of the book collections, easier approaches to the collections in the form of systematically arranged catalogues, open shelves for free access, longer hours of services, [and] interlibrary lending [...]". xxvi Shared cataloging systems in Thailand started in the mid-1970s after UNESCO consulted with the National Library about implementing computer facilities and training local staff in international cataloging standards. ${ }^{\text {xxvii }}$ In 1981, the National Information System (Thai NATIS) was established, with approval from the Thai government coming in 1986. ${ }^{\text {xxiii }}$ Phadungath (1983) outlines the various bibliographic standards that were frequently used in Thailand in the early 1980s. She points to three organizations as having major roles in defining cataloging standards. These three organizations include, "the Thai Library Association, the National Library of Thailand, and the university 
libraries" (Phadungath, 1983, p. 199). In the early 1980s, the cataloging standards used included: the Anglo-American Cataloging Rules and Amphanwong's Cataloging Rules for Thai Books for bibliographic description; the Thai Library Association's Subject Heading for Thai Books and Subject Heading used in the Dictionary Catalogues of the Library of Congress for subject analysis and vocabulary control; and the Library of Congress Classification (LCC) and the Dewey Decimal Classification (DDC) for classification and notation building. ${ }^{\text {xxix }}$

In the late 1990s, Siripan ${ }^{\mathrm{xxx}}$ observes the cataloging trends in Thai academic and special libraries. For classification, LCC and DDC were still the main classification schemes, however those classification numbers were insufficient for describing Thai subjects. The majority of Thai academic and special libraries have been using Integrated Library System adopting USMARC and AACR2 in describing materials. A few academic and special libraries began cataloging electronic materials using translated fifteen-element Dublin Core metadata standard. Online public access catalogs (OPAC) from other libraries, OCLC's catalog service, and Cataloging-in-Publication (CIP) were the main sources of English cataloging records. For local collections, original cataloging is the common practice. Alternatively, catalogers may access OPACs of National Library of Thailand's and some academic libraries. In terms of subject cataloging, Siripan $^{\mathrm{xxxi}}$ lists four sources of subject headings including Thai Library Association Subject Headings, Library of Congress Subject Headings, Sears List of Subject Headings, and the subject heading list published by the Cataloging Librarian Working Group of the Thai Academic Libraries Cooperation. Some special libraries develop local thesauri for specific subject areas such as finance, agriculture, and science and technology. Personal name authority list was compiled by the National Library of 
Thailand. Corporate name authority is primarily based on the published compilation of the Cataloging Librarian Working Group of the Thai Academic Library Cooperation.

The first academic library networks began in 1986 with the Provincial University Library Network (PULINET), started by Chiang Mai University library for university libraries in the provinces. ${ }^{x x x i i}$ Bangkok Metropolitian area libraries established the Thai Academic Libraries Network (THAILINET (M)) in 1992. ${ }^{\text {xxxiii }}$ These two networks combined in 1998 to create the Thai Library Integrated System (THAILIS). ${ }^{\text {xxiv }}$ In 2003, the Thai Union Catalog of Academic Libraries (UCTAL) (http://uc.thailis.or.th/) was established based on the THAILIS network. ${ }^{x x v}$ By 2018, according to the statistics reported on its website, eighty-six (86) academic libraries contribute more than two million bibliographic records to this initiative.

\section{Methodology}

During the first two weeks of November 2018 a focus group and series of interviews were conducted in order to understand more about Thai catalogers' use and perception of cataloging standards. Follow-up interviews were conducted in early 2019. The following section outlines the research questions, data collection, participant recruitment, and data analysis used in this study.

\section{Research questions}

Two questions guided this research.

- How do Thai catalogers use cataloguing standards in practice?

- What are Thai catalogers' perceptions about the standards they use?

\section{Data collection}

Data collection methodologies included a focus group and a series of semi-structured interviews. Deductive themes related to cataloging processes framed question 
development for both data collections. Questions focused on use and perception of cataloging standards related to descriptive cataloging, subject cataloging, classification, library systems, and sources of cataloging records. Appendix A includes the questions used for the focus group, while Appendix B includes the structured interview questions guiding the interviews.

\section{Participant recruitment-Focus Group}

Participants of a presentation and workshop held at Chulalongkorn University were asked if they wanted to participate in a voluntary focus group held on November 2 , 2018. The advertisement for the presentation and workshop listed target audiences of library catalogers, metadata specialists, knowledge organizers, system librarians, and library automation system administrators. Requirements for participation in the focus group included being based in Bangkok and its vicinities and being interested or involved in library cataloging and/or classification.

\section{Participant recruitment_-Interviews}

Interview recruitment was conducted via stratified sampling based on different library types. The initial goal was to recruit one participant from each of the following four library types: academic, public, national/governmental, and special. A snowball recruitment technique was employed to recruit further participants. Initial interviews were conducted from November 3-14, 2018. Follow-up interviews were conducted in early 2019 to clarify participant statements and confirm cataloging work practices.

\section{Data analysis}

Recordings from the focus group and interviews were analyzed using a modified RITA method, ${ }^{\mathrm{xxxvi}}$ which emphasizes quick coding of recordings with little transcription. Notes were taken by both researchers and assisted in the coding process. Deductive 
thematic analysis techniques were used to analyze the data, following steps outlined by the University of Auckland. ${ }^{\text {xxxvii }}$ The analysis process included: familiarization with the data, coding, searching for themes, reviewing themes, and defining/naming the themes before writing up the results.

\section{Data coding}

Cataloging standards and software can fall into one of 5 different categories: descriptive cataloging, subject cataloging, classification, systems/software, and sources of cataloging records. These four categories create a framework for deductive thematic analysis when examining cataloging practice. Both authors individually reviewed notes and recordings to deductively assign processes and practices to the four categories.

\section{Findings}

Findings are presented in five sections. Demographic information from the focus group and interviews are discussed first. Next, findings related to the four deductive codes reflecting library cataloging processes mentioned earlier, are presented.

\section{Demographics}

The focus group was held on November 2, 2018 at Chulalongkorn University. A total of 10 participants attended the focus group. Participants included three academic librarians, two special librarians, one library vendor, one retired librarian, and four library school faculty members. All participants were interested in the role that knowledge organization systems and cataloging played within Thai library environments. The focus group was conducted in a combination of both Thai and English languages.

Initial interviews were held from November $3^{\text {rd }}$ to $14^{\text {th }} 2018$ with people who identified as catalogers and/or were tasked with cataloging (or metadata) related 
activities in their libraries. Interviews occurred at the interviewees' places of work and half of the interviews were attended by more than one person. Interviews were conducted in Thai, English, or a combination of both languages. Table 1 shows demographic information related to interviews.

[Table 1 inserted here]

\section{Descriptive cataloging}

Participants in both the focus group and interview indicated using AACR2, RDA, or being unaware that descriptive cataloging standards exist. Out of the six interviews, two groups use RDA, two use AACR2, and two do not seem aware of descriptive standards. The two groups that showed a lack of awareness of descriptive standards either transcribed metadata from the piece itself or from other library public catalog interfaces.

Focus group participants commented that the main reason that libraries have not moved from AACR2 to RDA was that staff had no time to learn RDA; coordinate the change; or modify systems accordingly. One participant from a follow-up interview commented that although she was aware of RDA and has participated in training sessions about RDA, she still needed to "really really understand" the standard, particularly learning about the rationales rather than just following the instructions. One focus group participant pointed out that the Thai Union catalogue, a main cataloging record sharing system for Thai libraries, was not set up to accommodate RDA. Even libraries that have transitioned to RDA have older catalog records in AACR2. Consensus from the focus group also indicated that Thai librarians as a community have not discussed transitioning from AACR2 to RDA in a unified way. 


\section{Subject cataloging}

When focus group participants were asked about the most difficult part of the cataloging process, only three of the ten participants responded. Two focus group participants chose subject cataloging as the most difficult part of the cataloging process. Focus group participants pointed to the decision process involved in applying controlled vocabularies as creating the difficulty. Translating English terms into Thai is also a challenging task. One participant from an academic library addressed that their library has to consult academic scholars regularly to decide on terms to be used.

Awareness and discussion about subject cataloging was quite active during most interviews. Five out of six interview groups applied subject headings to materials. Only the school library showed a lack of awareness about subject cataloging. Interview participants indicated that a variety of controlled vocabularies are used within Thai libraries. Vocabulary use depended on the subject focus of the library, as well as the language of the collection. The academic and special library participants work in environments where materials are available in Thai as well as English. Vocabularies used are Library of Congress Subject Headings (LCSH) in English; Library of Congress Subject Headings translated into Thai; Phanmeka's book ${ }^{\mathrm{xx} x v i i i}$ on subject headings, translations of Sears List of Subject Headings; Medical Subject Headings (MeSH); userbased folksonomies; and a controlled vocabulary developed and maintained by Thai Academic Libraries Consortium. The vocabulary developed by Thai Academic Libraries Consortium is used by all five of the libraries that perform subject cataloging. One academic medical library reported during an interview that in addition to MeSH and the Thai Academic Libraries Consortium's controlled vocabulary, they maintain their own controlled vocabulary specifically for Thai collection.

The controlled vocabulary created by the Thai Academic Library Consortium has been implemented for a few decades and is widely used across the consortium's 48 
member libraries. The structure of the vocabulary is based on Library of Congress Subject Headings and available online. All members can suggest new terms. The consortium meets every two months to discuss and approve terms to enter into the database. While there is no written rule, the group relies heavily on the terms approved by the Royal Society of Thailand, a national academy which has an authority on the regulation of official Thai language including transcription and romanization systems. The documents published by this group are the meeting minutes which are available only in Thai.

\section{Classification}

Focus group participants indicated that multiple classification systems are used by Thai libraries, including Dewey Decimal Classification (DDC), National Library of Medicine (NLM), and Library of Congress (LCC). A variety of cutter systems are also being used with the two most popular having been created by the National Library of Thailand and Thammasat University respectively.

All six interview participants conduct some type of notation building using classification schemes. Interview participants indicated using the schemes identified by focus group participants, but also included customized library-made classification systems. DDC was used by four of the six library groups interviewed. The local translations of DDC have been published and updated by Phanmeka ${ }^{\mathrm{xxxix}}$. Most libraries using DDC primarily rely on print for both English and Thai versions. Multiple classification schemes were used in two of the six libraries visited. The government library created customized classification schemes for inherently Thai subject collections, such as Buddhism and Thai poetry. 


\section{Library systems}

Topics that came up during the interviews, but not the focus group, were library management system (LMS) and cataloging network use. All six interview participants indicated using some type of electronic library management system. The academic, government, and special libraries use commercially available integrated library systems. The public library interviewed uses an open source software LMS that uses UNIMARC, but the cataloging staff were not trained in MARC field usage. The school library uses an older commercial database with backend functionality only and no MARC encoding. No user interface is provided due to financial reasons and the lack of patron use in previous years.

None of the initial interview participants indicated sharing cataloging records in international cataloging networks, like OCLC WorldCat. A total of 22 Thai institutions are OCLC members and of that group 19 are academic libraries. Follow-up interview results suggest that a few academic libraries are in the early stages of cleaning and migrating records to OCLC. Some academic libraries who were the early adopters have left the cooperative cataloging program due to restricted resources. Other participating institutions are still evaluating the costs and benefits to participate such an international program.

The academic and medical library share records in the Thai Union Catalog. However, some participants commented that they are uncertain whether the Union Catalog is up to date since they have not been recently contributing. The government and public libraries share records with their own library branches only.

\section{Sources of Cataloging Records}


Copy cataloging is a common practice among interview participants. However, the practice in copying cataloging records are varied primarily based on language of collection described and accessibility of cataloging sources.

For English cataloging records, OCLC is one of the major sources of cataloging records for a couple of member libraries participated in the interview. Nonetheless, the participants commented that their contribution to English cataloging records are quite passive (i.e., only updating records locally and less likely to updating the global records). Other sources of English cataloging records for both OCLC member and nonmembers include Library of Congress, OhioLink, Library Hub Discover (previously COPAC), and National Library of Australia. For cataloging Thai collection, other academic libraries' cataloging records are the major sources, while the National Library of Thailand are less likely to be used as a source due to interoperability issue.

Interoperability seems to play an important role when selecting a source. A couple of participants only go to libraries that allow access via Z39.50 protocol or direct download/display MARC formatted records on OPAC interface. For the participants who are not OCLC members, they sometimes copy and paste records from WorldCat and other libraries' user interfaces.

According to the interview participants, copy cataloging is quite a common practice for cataloging English materials, while they perform more original cataloging practice for Thai materials. One special library commented that copying cataloging records of Thai materials from other libraries can be troublesome for certain titles especially when using ISBN to locate the records. The registration process of ISBN, regulated and enforced by the National Library of Thailand, is still less effective. For instance, multiple editions use the same ISBN. A large number of locally distributed books (e.g., memorial or funeral books, Buddhist teaching books) do not have ISBN 
assigned. Additionally, since it focuses more on patrons' access, Thai Union Catalog of Academic Libraries has yet developed functions to facilitate copy cataloging. Therefore, the participants who copy cataloging bibliographic records of Thai materials only rely on a few academic libraries whose OPACs allow interoperability functions.

\section{Analysis and Next Steps}

While the results section presented earlier reports on the use of cataloging standards, the analysis section reports on the perceptions of the relevance and usefulness of those standards within the Thai context. In addition, this section discusses common themes and issues that were presented throughout the interviews. A series of recommendations will also be presented.

One approach to the "internationalization" of cataloging standards has been translation, which is the process of translating the cataloging standard from English into other languages. Resources such as the Dewey Decimal Classification (DDC) System and Library of Congress Subject Headings (LCSH) have been translated from English into Thai. As would be expected, all of the Thai libraries consulted have collections in Thai, but all except the school library also have extensive English language collections. Participants noted that those English language collections benefited from descriptions from English language-based international cataloging standards. In contrast, Thai materials on certain inherently Thai topics did not match up well with these direct translated standards. Participants indicated that certain topics, such as traditional Thai medicine, Buddhism, and Thai poetry, were not well represented by the international cataloging standards, as previously observed by Siripan ${ }^{\mathrm{x}}$. Because of this lack of representation, libraries frequently create their own classification or subject heading scheme to better represent those areas of culture that are important to library users. 
Customized classification schemes are being created and used in many of these library environments. The IFLA Cataloging Section's (2016) cataloging principles point to focusing on the user as the key part of the cataloging process. For that reason, many libraries create specialized classification and subject themes to better support local users. The government library interviewed in this study created its customized classification schemes by expanding on already available international standards (in this case DDC) and consulting with Thai researchers who are subject specialists. The governmental library perceives their classification schemes as being better representation of Thai materials than that which is available using DDC alone. This classification scheme is not widely shared though, neither in Thailand nor internationally. Also, while the library does look to consult other countries' National Library Catalogs when creating records, they do not share their records at all. Because of this, the potential for the international cataloging community to have access to this customized classification scheme is limited, at best.

Sharing and reuse are key components of library cataloging and this is achieved through interoperability. Record sharing in particular is a way that libraries can make cataloging more affordable. Interoperability is indicated as the second most important factor according to IFLA's International Cataloging Principles. ${ }^{x l i}$ With the Thai Union Catalog still using AACR2 and Thai librarians, as a community, not having made a collaborative decision about transitioning to RDA as well as lacking of cooperative cataloging platform, sharing records beyond an institutional or system level is difficult due to a lack of interoperability. Thai librarians should be sharing records based on Thai materials, not only with each other, but internationally because they are the experts on these materials and subjects. These records, if shared internationally, could have a great impact on the Thai library community as a whole should discuss the implications and 
impact of not all using the same descriptive standard. Since only 22 Thai libraries have access to OCLC, this implies that most Thai records in that are not created by libraries in Thailand. More research will need to be conducted to understand the nuances of how using multiple descriptive standards has impacted Thai cataloguing practices.

Academic libraries are the local leaders in using, developing, and sharing cataloging standards. These results agree with research from 20 years ago,

[i]n general, university libraries are much more developed than other types of libraries in Thailand particularly in terms of recognition, status, services, and technology. Factors contributing to such development include substantial funds allocation from the government and their parent institutions, support from the public, and well-trained professional librarians at the master's and doctoral levels." xlii

A major contribution to the Thai cataloging community is the controlled vocabulary that is created and maintained by the academic library community. All of the libraries interviewed, except the school library, use this resource for describing Thai materials. The vocabulary is shared online via a searchable interface and updated multiple times a year. While all libraries in Thailand have access to the vocabulary, only the academic library members that maintain it are able to suggest and add new terms. Making the term suggestion process more open so that other types of libraries can suggest terms may make the resource even more useful for the Thai library community.

Across all interviews, the school library stuck out as where cataloging standards were seen as less important and not well implemented. These results support previous research which indicated that, "school libraries of different organizations and agencies greatly vary in terms of development, administration, funding, library buildings and facilities, library collections, cataloging, and classification systems, personnel and 
problems." "liii The school library was the most rural of all the libraries consulted and may not reflect the experience of all school libraries

\section{Limitations}

Due to the limited time frame for the interviews and focus group, only a small number of librarians and libraries were consulted. All libraries and librarians involved in the interviews were from central Thailand, with a particular concentration of libraries in Bangkok. Interview data may not be generalizable beyond the Bangkok/Central Thailand area.

\section{Conclusion}

This paper aims to shed some light on the current practice of cataloging standard in Thailand and what Thai cataloging librarians perceive about their practices. While cataloging standards have been continuously developed in the international level, there are numerous challenges in applying universal cataloging standards in Thailand. The ability to customized library management systems play an essential role in how cataloging librarians make changes in their practice. While language and resources (including time and finance) have also been claimed as barriers, Thai libraries, have been attempting to adopt international cataloging standards to various degrees. The cost of sharing (both in relation to monetary and staffing levels) is perceived as too high for many Thai libraries to truly participate in online communities (like OCLC). Therefore efforts in using cataloging standards are implemented with lack of feedback from the Thai cataloging community. As a result, a number of libraries maintain their records for internal access, with sharing as a lesser concern.

This study points to the challenges that libraries in specific contexts deal with cataloging at a local level. In contrast, global cataloging developments are more focused on sharing and networks. While international cataloging standards express concerns 
about flexibility in diverse contexts, the primary challenge of the cataloging community on a global scale is perhaps not about what collections are missing from shared systems, but how can 'international' standards be built through engagement with small and unique communities

\section{Acknowledgement}

This project is partially supported by the Arc of Memory Research Unit and the Behavioral Research and Informatics for Social Science Research Unit, Chulalongkorn University and Curtin University's School of Media, Creative Arts, and Social Inquiry's Small Grants program.

\section{Tables}

Table 1. Interview Demographic Information

\begin{tabular}{|c|c|c|c|c|c|}
\hline Interview & Date & Type of & & Language of & No. of \\
ID & Interviewed & Library & Source of funding & interview & Interviewees \\
\hline SchL 1 & $11 / 03 / 2018$ & school & government & Thai & 1 \\
\hline AcL 1 & $11 / 05 / 2018$ & academic & university & English & 4 \\
\hline MedL 1 & $11 / 07 / 2018$ & special-medical & university & English and Thai & 2 \\
\hline ArL 1 & $11 / 09 / 2018$ & special-art & government and private & Thai & 1 \\
\hline GovL 1 & $11 / 12 / 2018$ & government & government & Thai & 3 \\
\hline PubL 1 & $11 / 14 / 2018$ & public & city government and & English & 1 \\
\hline
\end{tabular}

\section{Appendices}

\section{Appendix A Focus Group Questions}


1. By show of hands, what type of library do you work in: academic, public, national/governmental, or special?

2. What type of cataloguing resources do you use at your job?
a. For subject headings?
b. For call numbers?
c. For descriptions?

3. By a show of hands, who thinks that:

a. creating subject headings is the hardest task

b. creating call numbers is the hardest task

c. creating descriptions is the hardest task

4. Based on the responses to question 2:

a. Why is subject heading creation process the hardest task?

b. Why is call number creating the hardest task?

c. Why is creating descriptions the hardest task?

5.Have you ever created your own knowledge organization system before? If so, tell me about the experience?

\section{Appendix B Semi-structured interviews}

1. Tell me about your work.

2. What type(s) of training and qualifications did you have obtain to get to do this job?

3. What type of materials do you catalog most frequently?

(Focus group questions reviewed also in semi-structured interviews)

ii Hope Olson, “Mapping Beyond Dewey’s Boundaries: Constructing Classificatory

Space for Marginalized Knowledge Domains," Library Trends. 47 no.2 (1998): 233 -

254; Elaine Svenonius, The Intellectual Foundation of Information Organization

(Cambridge, MA: The MIT Press, 2001); Suzanne Briet, What is Documentation?:

English Translation of the Classic French Text (Lanham, Maryland: Scarecrow Press, 
2006); Hollie White, “Decolonizing the Way Libraries Organize,” paper presented at IFLA 2018: $84^{\text {th }}$ IFLA General Conference and Assembly, Kuala Lumpur, Malaysia, August 24-30, 2018.

iii William Denton, "FRBR and the History of Cataloging," in Understanding FRBR: What It Is and How It Will Affect Our Retrieval, Arlene G. Taylor ed.(Westport, Connecticut: Libraries Unlimited), 35-57.

iv Pat Riva. "National Bibliographic Register”. IFLA Metadata Newsletter 3 no. 2 (December 2017): 26-28. Accessed July 30, 2019, https://www.ifla.org/files/assets/cataloguing/scatn/metadata_newsletter-20171229.pdf ${ }^{v}$ Riva, IFLA Metadata Newsletter,27.

vi Aurathai Waressa-ard, “The Role of Academic Libraries in Developing an Automated Library Network in Thailand," The Journal of Academic Librarianship 30 no. 6 (2004): 502-06.

vii Stephen Massil, "Possibility of Establishing a Computerized Catalogue of Thai Materials at the National Library of Thailand: Report Prepared for the Government of Thailand by the United Nations Educational, Scientific, and Cultural Organization (Unesco)," (UNESCO Technical Report FRM/CC/DBA/76/127, 1976).

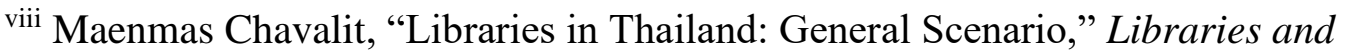
Librarianship in Thailand From Stone Inscription to Microchip (Bangkok, Thailand: IFLA '99 National Organizing Committee, August 1999), 1-2; Chirawan Bhakdibutr and Sutannee Keesiri, "University Libraries in Thailand," Libraries and Librarianship in Thailand From Stone Inscription to Microchips, (Bangkok, Thailand: IFLA '99 National Organizing Committee, August 1999), 17-21. 


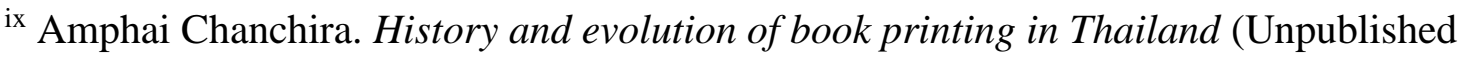
master thesis) (Bangkok, Thailand:Chulalongkorn University, 1972). Accessed July 30, 2019, http://cuir.car.chula.ac.th/handle/123456789/22854

${ }^{x}$ Chavalit, "Libraries in Thailand," 2; Bkakdibutr and Keesiri, "University Libraries," 18.

xi Chavalit, "Libraries in Thailand," 2.

xii Massil, "Report," 7.

xiii Bkakdibutr and Keesiri, "University Libraries," 17; Waressa-ard, "Role of Academic Libraries," 502

xiv Bkakdibutr and Keesiri, "University Libraries," 18.

${ }^{x v}$ Somsuang Prudtikul and Supamas Na Thalang, "School Libraries in Thailand," Libraries and Librarianship in Thailand From Stone Inscription to Microchips (Bangkok, Thailand: IFLA '99 National Organizing Committee, August 1999), 22-25. ${ }^{\text {xvi }}$ Kulthorn Lerdsuriyakul, "Public Libraries in Thailand," Libraries and Librarianship in Thailand From Stone Inscription to Microchips. (Bangkok, Thailand: IFLA '99 National Organizing Committee), 32-37. xvii Lerdsuriyakul, "Public Libraries," 34.

xviii Praditta Siripan, "Special Libraries in Thailand as the Libraries Turn to the Year 2000," Libraries and Librarianship in Thailand From Stone Inscription to Microchips, (Bangkok, Thailand: IFLA '99 National Organizing Committee, 1999), 26-31. ${ }^{\text {xix }}$ Siripin, "Special Libraries," 27. ${ }^{x x}$ Charuvarn Sindusopon, "Status of Thai Librarians in Society; An Observation," Libraries and Librarianship in Thailand From Stone Inscription to Microchips. (Bangkok, Thailand: IFLA '99 National Organizing Committee, 1999), 84-91. xxi Piyapat Jarusawat, Andrew Cox, and Jo Bates, "Community participation in the management of palm leaf manuscripts as Lanna cultural material in Thailand," Journal of Documentation, 74, no. 5 (2018): 951-965. 
xxii Songphan Choemprayong and Thamtheerasatien, "Measuring usage of printed collection in a non-circulating design library: An evidence-based multidimensional evaluation" (paper presented at the $6^{\text {th }}$ International Conference on Quantitative and Qualitative Methods in Library, Istanbul, Turkey, May 2014).

xxiii Chutima Sacchanand, "Thai Library Association: Under the Royal Patronage of Her Royal Highness Princess Maha Chakri Sirindhorn," Libraries and Librarianship in Thailand From Stone Inscription to Microchips, (Bangkok, Thailand: IFLA '99 National Organizing Committee, 1999) 9-16. xxiv International Federation of Library Associations, "Thailand Country Report," IFLA/FAIFE World Report 2007. 367-369. Accessed July 31, 2019, https://www.ifla.org/files/assets/faife/publications/ifla-world-report/119_iflafaife_2007_cr_- thailand.pdf ${ }^{\mathrm{xxv}}$ Sinduspon, "Status of Thai Librarians," 85. xxvi Sinduspon, "Status of Thai Librarians," 85. xxvii Massil, "Possibility," 3. xxviii Uthai Dhutiyabhodhi, “Thai National Information System (Thai Natis)," Libraries and Librarianship in Thailand From Stone Inscription to Microchips. (Bangkok, Thailand: IFLA '99 National Organizing Committee, 1999), 3-7.

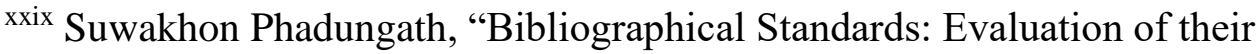
Implementation in Thailand," (paper presented at The Library in the Information Revolution: Proceedings of the Sixth Congress of Southeast Asian Libraries, Singapore 30 May-3 June 1983), 199-209.

${ }^{x x x}$ Praditta Siripan, "Metadata and Trends of Cataloging in Thai libraries," (paper presented at the $65^{\text {th }}$ IFLA Council and General Conference Program and Proceedings. Bangkok, Thailand, 1999), Accessed on July 31, 2019. 
xxxi Siripan, "Metadata and Trends", 4.

xxxii Bhakdibutr, "University Libraries," 18; Waressa-ard, "Role of Academic Libraries," 504.

xxxiii Bhakdibutr, "University Libraries,” 18.

xxxiv Bhakdibutr, "University Libraries," 19.

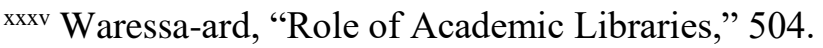

xxxvi Jennifer Watling Neal, Zachary P Neal, Erika VanDyke, and Miriah Kornbluh.

"Expediting the Analysis of Qualitative Data in Evaluation: A Procedure for the Rapid Identification of Themes from Audio Recordings (RITA)," American Journal of

Evaluation. 36, no. 1 (2015), 118-132.

xxxvii University of Auckland School of Psychology, "About thematic analysis" (n.d),

Accessed July 31, 2019, https://www.psych.auckland.ac.nz/en/about/our-

$\underline{\text { research/research-groups/thematic-analysis/about-thematic-analysis.html }}$

xxxviii Pawa Phanmeka, DDC 22: Dewey Decimal Classification based on the 22th

Edition (in Thai). 2nd Ed. (Bangkok, Thailand: Department of Library and Information Science, Faculty of Humanities, Srinakarinwirote University, 2011).

xxxix Phanmeka, "DDC 22".

${ }^{\mathrm{xl}}$ Siripan, "Metadata and Trends," 27.

${ }^{x l i}$ IFLA Cataloguing Section and IFLA Meetings of Experts on an International

Cataloguing Code, Statement of International Cataloguing Principles (ICP).

(Netherlands: International Federation of Library Associations and Institutions, 2016)

Accessed on July 31, 2019.

https://www.ifla.org/files/assets/cataloguing/icp/icp 2016-en.pdf

xlii Bhakdibutr, "University Libraries," 18.

xliii Prudtikul, "School Libraries," 22. 